\title{
The ACRL Conferences: A Profile of its Presenters
}

\section{Joseph Fennewald}

\begin{abstract}
This study provides a profile of the authors of contributed papers at the first twelve ACRL conferences. It found that the conference presenters tend to be female academic librarians (administrators, reference librarians, and subject specialists) from Doctoral Research institutions in the Midwest. It also discovered several trends. During its 27-year history, there have been increases in the number of female authors, library school faculty giving papers, and authors from master's and baccalaureate institutions. In addition, the rate of collaboration has grown. The profile and its related trends were very similar to what has been reported in $C \& R L$ authorship studies-with one exception. Women are more likely to appear as conference presenters than journal authors. Further research should explore the role of gender in scholarly communication.
\end{abstract}

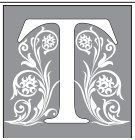

he Association of College \& Research Libraries (ACRL) conference is considered to be the leading conference for academic librarians. As "the only conference dedicated to meeting the needs of academic librarians," ${ }^{11}$ several thousand attend its biennial meetings. Reviews of its sessions appear in College $\mathcal{E}$ Research Libraries News as well as a number of other publications. Its contributed papers are published in the conference proceedings. These proceedings serve as an important record of the issues facing the profession. They also help academic librarians identify the leading researchers and practitioners in their field.

The objective of this research is to profile the authors of the papers presented at the first twelve ACRL conferences. It explores several questions: Who gives papers at these conferences? What regions and institutions do they represent? Have there been any changes in this profile during the conference's 27-year history? The papers are typically a combination of research reports and case studies on best practices. ${ }^{2}$ It is possible not only to identify who is doing research by examining their authors, but it is also possible to identify the institutions that serve as the basis for best practices.

\section{Literature Review}

Although the literature on library conferences has been described as plentiful, it is composed primarily of personal accounts and meeting reports. ${ }^{3}$ There are very few systematic studies of these events. The ACRL conference has been the subject of only four. Caroline Coughlin and Pamela Snelson (1983) and Pamela Snelson and S. Anita Talar (1991) examined the papers given at the first four conferences for research content. ${ }^{4}$ Joseph Fennewald (2005) explored the subsequent publica-

Joseph Fennewald is Head Librarian at Penn State University, Hazleton Campus; e-mail: Jaf23@psu.edu. 
tion rate of presentations at the 9th ACRL conference. ${ }^{5}$ Finally, Anne L. Buchanan, Edward A. Goedeken, and Jean-Pierre V. M. Hérubel (1996) describe the authors and subject content of "theme papers, contributed papers, and program or discussion papers" at the 1st through the 6th ACRL conferences. ${ }^{6}$ This study expands upon the Buchanan, Goedeken, and Hérubel research.

Unlike the literature on conferences, there have been many studies of library journals, several of which have concentrated specifically on authors. At the time of his study, Thomas E. Nisonger (1996) identified 21 previous authorship studies. $^{7}$ Of these, four focused exclusively on the authors of ACRL's flagship journal, College $\mathcal{E}$ Research Libraries (CERL), ${ }^{8}$ and several more included $C \mathcal{E} R L$ in their comparisons with other library journals. ${ }^{9}$ Adapting the methodology used in these studies will provide the opportunity to compare authors of conference papers with authors of library journal articles.

\section{Methodology}

This study draws on the procedures utilized in authorship studies of library journals. It specifically examines the geographic distribution, institutional affiliation, occupational title, and gender of authors of contributed papers given at twelve ACRL conferences. For geographic distribution, each presenter received a regional classification based on their institutional affiliation. Five United States regions, as first described by John Olsgaard and Jane Olsgaard (1980), were used: Northeast, Southeast, Midwest, Southwest, and the West. ${ }^{10}$ Presenters could also be classified as International. The academic institution was classified by its 2002 Carnegie Classification using the National Center for Education Statistics' Web site. ${ }^{11}$ Similar classifications were collapsed. Thus, Doctoral Research I and Doctoral Research II institutions were simply identified as Doctoral Research institutions. The presenter's occupational title was generally categorized as academic librarians, faculty and students from library and information science programs, faculty and students from other academic programs, and other. When the title was not listed in the program, the American Library Directory or the institution's Web site was searched. In addition, academic librarians were further classified using the 21 subcategories listed in the ACRL membership survey. ${ }^{12}$ When speakers gave more than one title (i.e., Reference Librarian and Bibliographic Instructor) they were coded by the first listed. The gender of each presenter was also coded. To classify ambiguous names, foreign names, or the use of initials, an Internet search on the person's name was conducted.

The data were organized in threeconference intervals to consider trends obscured by year-to-year comparisons. Data were analyzed for coauthors as well as for first or sole authors. As James L. Terry wrote, "disregarding coauthors misrepresents the extent and nature of authorship." 13

Only the authors of contributed papers were included because the submission process for papers is similar to that of research articles. "Papers are reviewed in a blind referee process with final selection of papers being recommended by at least two reviewers."14 Theme papers, invited papers, and panel sessions are not subjected to this procedure and were therefore omitted.

\section{Findings}

Initially held every three years, the ACRL conference has been held biennially since 1995. The conferences have been well attended, with each of the past seven events achieving record attendance. (See table 1.) To date, 983 authors have presented 636 papers in twelve conferences. ${ }^{15}$

The acceptance rate for papers at the seven conferences ranged from 25 to 46 percent, for an average of 32 percent. The CERL has a similar acceptance rate of 35 percent. ${ }^{16}$ Thus, it appears to be as difficult to have a paper accepted at the ACRL conference as it is to have it ac- 


\begin{tabular}{|c|c|c|c|c|c|c|c|}
\hline & ACRL & $\begin{array}{r}\text { onferences, Loc: } \\
\text { Attendance }\end{array}$ & $\begin{array}{l}\text { TABLE } \\
\text { tion, A } \\
\text { and Ac }\end{array}$ & $\begin{array}{l}1 \\
\text { thors, } \\
\text { ceptan }\end{array}$ & $\begin{array}{l}\text { Contribut } \\
\text { ce Rate }\end{array}$ & ed Paper: & \\
\hline Conference & Year & Location & Authors & Papers & Attendance & $\begin{array}{l}\text { Ratio of } \\
\text { Attendance } \\
\text { to Papers }\end{array}$ & $\begin{array}{c}\text { Acceptance } \\
\text { Rate }\end{array}$ \\
\hline I & 1978 & Boston, MA & 89 & 66 & 2,625 & 40 & - \\
\hline II & 1981 & Minneapolis, MN & 73 & 56 & 1,881 & 34 & - \\
\hline III & 1984 & Seattle, WA & 71 & 47 & 1,754 & 37 & $28 \%$ \\
\hline IV & 1986 & Baltimore, MD & 85 & 60 & 2,309 & 28 & $31 \%$ \\
\hline V & 1989 & Cincinnati, $\mathrm{OH}$ & 112 & 77 & 2,887 & 37 & $38 \%$ \\
\hline VI & 1992 & Salt Lake, UT & 86 & 52 & 2,241 & 43 & - \\
\hline VII & 1995 & Pittsburgh, PA & 82 & 54 & 2,721 & 56 & $46 \%$ \\
\hline VIII & 1997 & Nashville, TN & 60 & 40 & 2,973 & 74 & - \\
\hline IX & 1999 & Detroit, MN & 85 & 54 & 3,080 & 57 & - \\
\hline $\mathrm{X}$ & 2001 & Denver, CO & 80 & 42 & 3,388 & 81 & $25 \%$ \\
\hline XI & 2003 & Charlotte, NC & 76 & 42 & 3,490 & 83 & $30 \%$ \\
\hline XII & 2005 & Minneapolis, MN & 84 & 46 & 4,000 & 87 & $25 \%$ \\
\hline I-XII & $\begin{array}{l}1978- \\
2005\end{array}$ & & 983 & 636 & $\begin{array}{r}2,779 \\
\text { avg. }\end{array}$ & 55 avg. & $32 \%$ avg. \\
\hline
\end{tabular}

cepted for publication in CERL. At the same time, it is interesting to note that the number of papers presented has been declining, while attendance has been increasing.

\section{Geographic Distribution}

There were a higher proportion of authors from institutions in the Midwest, most notably Illinois, than from any other region. Thirty-three to 45 percent of all authors, an average of 38 percent, were Midwestern. This was followed by authors in the Northeast (averaging 20\%), the West $(17 \%)$, the Southeast (13\%), and the Southwest (10\%). As seen in table 2, representation by region followed this pattern for all conferences, with minor exceptions in the periods 1986-1992 and 1995-1999. In 1986-1992, authors from the Southwest were slightly better represented than in other periods. From 1995 to 1999, there was a larger representation of authors from the Northeast. Conference location might explain these variations, but further analysis did not support this.

\begin{tabular}{|l|c|c|c|c|c|c|c|c|}
\hline \multicolumn{10}{|c|}{ TABLE 2 } \\
Geographic Distribution of All Authors, ACRL Conferences \\
\hline \hline Conference & Years & Midwest & Northeast & West & Southeast & Southwest & Int'l & $(\mathbf{N})=100 \%$ \\
\hline I-III & $1978-84$ & $34 \%$ & $21 \%$ & $21 \%$ & $12 \%$ & $8 \%$ & $5 \%$ & $(231)$ \\
\hline IV-VI & $1986-92$ & $45 \%$ & $14 \%$ & $14 \%$ & $11 \%$ & $15 \%$ & $1 \%$ & $(282)$ \\
\hline VII-IX & $1995-99$ & $33 \%$ & $29 \%$ & $15 \%$ & $10 \%$ & $9 \%$ & $4 \%$ & $(222)$ \\
\hline X-XII & $2001-05$ & $38 \%$ & $19 \%$ & $17 \%$ & $16 \%$ & $8 \%$ & $1 \%$ & $(238)$ \\
\hline I-XII & $1978-2005$ & $38 \%$ & $20 \%$ & $17 \%$ & $13 \%$ & $10 \%$ & $3 \%$ & $(973)^{*}$ \\
\hline *Ten speakers did not identify their place of employment. \\
\hline
\end{tabular}


TABLE 3

Geographic Distribution of All Authors Based on ACRL Conference Location

\begin{tabular}{|l|l|l|c|c|c|c|c|c|}
\hline \hline Conference & Location & Midwest & Northeast & West & Southeast & Southwest & Int'l & $\begin{array}{c}(\mathbf{N})= \\
\mathbf{1 0 0} \%\end{array}$ \\
\hline II, V, IX, XII & Midwest & $\mathbf{3 9 \%}$ & $20 \%$ & $18 \%$ & $12 \%$ & $8 \%$ & $3 \%$ & $(348)$ \\
\hline I, IV, VII & Northeast & $29 \%$ & $\mathbf{2 9 \%}$ & $15 \%$ & $11 \%$ & $11 \%$ & $4 \%$ & $(255)$ \\
\hline III, VI, X & West & $49 \%$ & $8 \%$ & $\mathbf{1 7 \%}$ & $15 \%$ & $11 \%$ & $1 \%$ & $(236)$ \\
\hline VIII, XI & Southeast & $31 \%$ & $25 \%$ & $14 \%$ & $\mathbf{1 4 \%}$ & $15 \%$ & $0 \%$ & $(134)$ \\
\hline I-XII & $38 \%$ & $20 \%$ & $17 \%$ & $13 \%$ & $10 \%$ & $3 \%$ & $(973)^{*}$ \\
\hline *Ten speakers did not identify their place of employment.
\end{tabular}

The location of the conference appears to have had only a minimal impact on the geographic distribution of paper presenters. There have been four conferences in the Midwest, three each in the Northeast and West, and two in the Southeast. There has never been an ACRL conference in the Southwest. Authors from the Midwest have dominated the conference wherever it was held with the exception of conferences in the Northeast, when authors from that region were as well represented as authors from the Midwest (29\% from both regions). Authors from the West and Southeast were perhaps slightly more likely to present when the conference was held in their region, but only marginally so at best.

\section{Institutional Affiliation}

As one would expect for an academic library conference, most speakers (93\%) represented institutions of higher educa- tion. Of the 908 speakers from academic institutions, 73 percent were employed by Doctoral Research institutions. Seventeen percent came from institutions in which the highest degree awarded was typically the master's. This was followed by seven percent from institutions awarding baccalaureate degrees. Only two percent represented other academic institutions, such as two-year and professional programs. (See table 4.)

In the past ten years there has been a slight shift in institutional types. In particular, there have been more speakers from master's and baccalaureate institutions since 1986. Comparing the 1986 to 1992 conferences with the 2001 to 2005 conferences, there was an increase of six percent in speakers from master's institutions. (See table 4.) There was also an eight percent increase in speakers from baccalaureate institutions. There is no evidence to suggest that ACRL is actively

\begin{tabular}{|c|c|c|c|c|c|c|}
\hline \multicolumn{7}{|c|}{$\begin{array}{c}\text { TABLE } 4 \\
\text { Carnegie Classification for All Authors from Academic Institutions, } \\
\text { ACRL Conferences }\end{array}$} \\
\hline Conferences & Years & $\begin{array}{l}\text { Doctoral/ } \\
\text { Research }\end{array}$ & Master's & Baccalaureate & Other & $(\mathrm{N})=100 \%$ \\
\hline I-III & $1978-84$ & $72 \%$ & $13 \%$ & $11 \%$ & $4 \%$ & (204) \\
\hline IV-VI & 1986-92 & $80 \%$ & $17 \%$ & $3 \%$ & $1 \%$ & (269) \\
\hline VII-IX & 1995-99 & $74 \%$ & $15 \%$ & $6 \%$ & $5 \%$ & $(211)$ \\
\hline $\mathrm{X}-\mathrm{XII}$ & $2001-05$ & $66 \%$ & $23 \%$ & $11 \%$ & $0 \%$ & (224) \\
\hline I-XII & 1978-2005 & $73 \%$ & $17 \%$ & $7 \%$ & $2 \%$ & $(908)^{*}$ \\
\hline
\end{tabular}


pursuing speakers from these institutions. (There has not been any significant change in the review process, for example.) Instead, this trend may reflect an increasing emphasis on research at master's and baccalaureate institutions.

Certain institutions appear frequently, suggesting that much of the research and the best practices case studies come from a core group. Based on the institutional affiliation of the primary author, there were 288 institutions represented in the 636 contributed papers given at the ACRL conferences. Of these, $170(27 \%)$ appeared only once, 102 appeared between two and five times, ten institutions appeared between six and ten times, and six institutions appeared more than ten times. (See table 5.) These six institutions were: University of Illinois at Urbana-Champaign, University of Illinois at Chicago, Pennsylvania State University, Cornell University, Ohio State University, and Georgia State University. When all authors were examined, these same institutions appeared among the top six.

Thus, much of the library research and best practices presented at the ACRL conferences comes from these six institutions.

\section{TABLE 5}

Institutional Frequency by Primary and All Authors, ACRL Conferences

\begin{tabular}{|c|l|c|}
\hline $\begin{array}{c}\text { Primary } \\
\text { Author }\end{array}$ & \multicolumn{1}{|c|}{ Institution } & $\begin{array}{c}\text { All } \\
\text { Authors }\end{array}$ \\
\hline 26 & $\begin{array}{l}\text { University of Illinois at } \\
\text { Urbana-Champaign }\end{array}$ & 48 \\
\hline 21 & University of Illinois at Chicago & 28 \\
\hline 21 & Pennsylvania State University & 27 \\
\hline 17 & Cornell University & 20 \\
\hline 15 & Ohio State University & 22 \\
\hline 11 & Georgia State University & 28 \\
\hline 9 & Southern Illinois University & 16 \\
\hline 7 & University of Arizona & 17 \\
\hline 7 & Texas A\&M & 15 \\
\hline 7 & Arizona State University & 13 \\
\hline 6 & University of California-Irvine & 14 \\
\hline 5 & Kent State University & 13 \\
\hline
\end{tabular}

\section{Productivity}

Although six institutions appeared most frequently, most authors, wherever they work, have given only one paper. Of the 983 ACRL presenters, 855 (87\%) gave one paper; 92 gave two; 25 gave three; 10 gave four each; and only one person has given five. The most prolific authors have given more than one paper at the same conference and/or contributed to more than one conference. Many achieved this by coauthoring papers with others, but a few were the sole authors of all the papers they presented. However, prolific authors, unlike the institutions they come

TABLE 6

Occupation of All Authors of Contributed Papers, ACRL Conferences

\begin{tabular}{|l|c|c|c|c|c|r|}
\hline \hline Conferences & Years & $\begin{array}{c}\text { Academic } \\
\text { Librarians }\end{array}$ & $\begin{array}{c}\text { Faculty-LIS } \\
\text { Affiliation }\end{array}$ & $\begin{array}{c}\text { Faculty-Other } \\
\text { Disciplines }\end{array}$ & $\begin{array}{c}\text { Other } \\
\text { Titles }\end{array}$ & $(\mathbf{N})=\mathbf{1 0 0} \%$ \\
\hline I-III & $1978-84$ & $94 \%$ & $1 \%$ & $0 \%$ & $6 \%$ & $(139)$ \\
\hline IV-VI & $1986-92$ & $91 \%$ & $6 \%$ & $0 \%$ & $3 \%$ & $(262)$ \\
\hline VII-IX & $1995-99$ & $90 \%$ & $7 \%$ & $2 \%$ & $0 \%$ & $(203)$ \\
\hline X-XII & $2001-05$ & $81 \%$ & $12 \%$ & $3 \%$ & $4 \%$ & $(236)$ \\
\hline I-XII & $1978-2005$ & $89 \%$ & $7 \%$ & $1 \%$ & $3 \%$ & $(840)^{*}$ \\
\hline
\end{tabular}

*It was not possible to identify the occupation title of 143 of the 983 speakers. 
from, are the exception at the ACRL conferences.

\section{Occupation}

As one would expect for a conference "dedicated to the needs of academic librarians,"17 almost all of its authors, 89 percent, have been academic librarians. However, the occupation profile has seen recent changes. In the first nine conferences, academic librarians represented between 90 and 94 percent of the authors. (See table 6.) For the last three conferences, the percentage of academic librarians dropped to 81 percent. As the percentage of academic librarians decreased, authors who are members of the faculty at library schools and other disciplines increased. Library school faculty increased from one to twelve percent. There has also been a slight increase $(2-3 \%)$ in the number of faculty from other academic fields (Biology, Communications, Education, English, History, and Psychology). Although academic librarians still dominate, faculties from library and information science programs, as well as those in other areas, are also presenting papers at the ACRL conferences in greater numbers.

\section{Occupational Titles of Academic Librarians} Of the 744 academic librarians, 656 could be placed in the 21 categories used to describe ACRL members. ${ }^{18}$ Five hundred twenty-two (80\%) were classified in just five areas-administrators, reference, subject specialists, circulation, and instruction. One hundred thirty-four were distributed into eleven separate categories. None of the authors fell into five categories - audiovisual/media, development, distance education, library liaison, and license administration.

Academic librarians giving ACRL conference papers tend to be administrators ${ }^{19}$, reference librarians, and subject specialists $^{20}$. Each area has seen an increase. The percentage of administrators went from 29 to 32 percent. (See table 7.) Reference librarians went from 12 percent at the first three conferences to 21 percent at the last three. The percentage of subject specialists went from 14 to 24 percent. For the first three conferences these three subcategories represented 55 percent of all academic librarians giving papers. For the last three conferences, they represented 77 percent.

The remaining two subcategories were represented in much smaller proportions. Circulation librarians ${ }^{21}$ constituted only 10 percent of the academic librarians giving papers. In the last three conferences, their representation decreased to four percent from an average of 12 percent at all previous conferences. (See table 7.) On the other hand, the percentage of contributing librarians whose primary role is instruction has been gradually increasing, as illustrated in table 7 .

\begin{tabular}{|c|c|c|c|c|c|c|c|}
\hline \multicolumn{8}{|c|}{$\begin{array}{c}\text { TABLE } 7 \\
\text { Academic Librarians' Presenting Papers by Occupational Title, } \\
\text { Top Five Subcategories }\end{array}$} \\
\hline Conferences & Dates & Administrators & Reference & $\begin{array}{c}\text { Subject } \\
\text { Specialist }\end{array}$ & Circulation & Instruction & $\begin{array}{l}(\mathrm{N})= \\
100 \%\end{array}$ \\
\hline I-III & 1978-84 & $29 \%$ & $12 \%$ & $14 \%$ & $12 \%$ & $1 \%$ & (110) \\
\hline IV-VI & 1986-92 & $23 \%$ & $17 \%$ & $20 \%$ & $11 \%$ & $6 \%$ & (209) \\
\hline VII-IX & 1995-99 & $22 \%$ & $25 \%$ & $11 \%$ & $12 \%$ & $8 \%$ & (169) \\
\hline $\mathrm{X}-\mathrm{XII}$ & $2001-05$ & $32 \%$ & $21 \%$ & $24 \%$ & $4 \%$ & $10 \%$ & (168) \\
\hline $\mathrm{I}-\mathrm{XII}$ & $\begin{array}{l}1978- \\
2005\end{array}$ & $26 \%$ & $19 \%$ & $18 \%$ & $10 \%$ & $7 \%$ & $(656)^{*}$ \\
\hline
\end{tabular}


The decrease in circulation librarians, and the increase in the other four groups, may reflect shifts in issues facing the profession. As libraries developed online catalogs in the late seventies, there was a greater representation of librarians from technical services. In more recent years, with an emphasis on information literacy and developing 24/7 reference services, there is a larger presence of reference and instruction librarians. Future research may want to explore the subject areas of the conference papers to identify the issues then facing the profession.

\section{Gender}

Women have given more papers than men have. The proportion of women authors was greatest in the early years. During the first six conferences, women presenters increased from 53 to 65 percent. (See table 8.) For the last six conferences, the number has remained relatively steady at 68 to 71 percent.

When only academic librarians were examined, it was found that the proportion of presenters who are women vary by their job title. Overall, 82 percent of the reference and instruction presenters and 73 percent of the subject specialists and circulation presenters have been women. (See table 9.) Of the top five subcategories, administrators had the smallest percentage of women. In this one occupational category, 55 percent have been female. However, this average is very similar

\section{TABLE 8}

Gender, All Authors of Contributed Papers, ACRL Conference

\begin{tabular}{|l|l|l|l|l|}
\hline Conferences & \multicolumn{1}{|c|}{ Years } & Female & Male & $\begin{array}{c}(\mathbf{N})= \\
\mathbf{1 0 0} \%\end{array}$ \\
\hline I-III & $1978-84$ & $53 \%$ & $47 \%$ & $(232)$ \\
\hline IV-VI & $1986-92$ & $65 \%$ & $35 \%$ & $(281)$ \\
\hline VII-IX & $1995-99$ & $68 \%$ & $32 \%$ & $(227)$ \\
\hline X-XII & $2001-05$ & $71 \%$ & $29 \%$ & $(239)$ \\
\hline I-XII & $1978-2005$ & $64 \%$ & $36 \%$ & $(979)^{*}$ \\
\hline
\end{tabular}

*It was not possible to identify the gender of four of the 983 presenters.

to the estimated percentage of female academic library administrators. ${ }^{22}$ Likewise, the average of all female academic librarians presenting papers was found to be 67 percent $^{23}$ - this is almost identical to the proportion of women in the profession, 68 percent. ${ }^{24}$ Thus, it appears that both genders are represented at the ACRL conferences in proportion to their numbers in the profession.

\section{Collaboration}

The majority of all papers given at the ACRL conferences had only one author (61\%). Yet, from 1978 to 2005, the percentage of single author papers has actually declined. (See table 10.) For the first three conferences, 70 percent of all papers had only one author. In the last three conferences, less than half, only 47 percent, had just one author. On the other hand, there has been a steady increase of papers with two or more authors. Papers with

\section{TABLE 9}

\section{Percentage of Female Authors in the Top Five Occupational Subcategories}

\begin{tabular}{|l|c|c|c|c|c|c|}
\hline \hline Conferences & Years & Administrators & Reference & $\begin{array}{c}\text { Subject } \\
\text { Specialists }\end{array}$ & Circulation & Instruction \\
\hline I-III & $1978-84$ & $56 \%$ & $62 \%$ & $73 \%$ & $77 \%$ & $*$ \\
\hline IV-VI & $1986-92$ & $57 \%$ & $72 \%$ & $74 \%$ & $87 \%$ & $69 \%$ \\
\hline VII-IX & $1995-99$ & $43 \%$ & $86 \%$ & $72 \%$ & $57 \%$ & $79 \%$ \\
\hline X-XII & $2001-05$ & $60 \%$ & $94 \%$ & $73 \%$ & $71 \%$ & $94 \%$ \\
\hline I-XII & $1978-2005$ & $55 \%$ & $82 \%$ & $73 \%$ & $73 \%$ & $82 \%$ \\
\hline
\end{tabular}

*The number of presenters was too small to calculate a reliable percentage. 


\begin{tabular}{|l|c|c|c|c|c|}
\hline \multicolumn{7}{|c|}{$\begin{array}{c}\text { TABLE 10 } \\
\text { Coauthorship of Contributed Papers, } \\
\text { ACRL Conferences }\end{array}$} \\
\hline \hline Conferences & Years & $\begin{array}{c}\text { Single } \\
\text { Author }\end{array}$ & $\begin{array}{c}\text { Two } \\
\text { Authors }\end{array}$ & $\begin{array}{c}\text { Three-Seven } \\
\text { Authors }\end{array}$ & $\begin{array}{c}(\mathbf{N})= \\
\mathbf{1 0 0} \%\end{array}$ \\
\hline I-III & $1978-84$ & $70 \%$ & $24 \%$ & $7 \%$ & $(169)$ \\
\hline IV-VI & $1986-92$ & $66 \%$ & $23 \%$ & $11 \%$ & $(189)$ \\
\hline VII-IX & $1995-99$ & $56 \%$ & $34 \%$ & $9 \%$ & $(148)$ \\
\hline X-XII & $2001-05$ & $47 \%$ & $32 \%$ & $21 \%$ & $(130)$ \\
\hline I-XII & $1978-2005$ & $61 \%$ & $28 \%$ & $11 \%$ & $(636)$ \\
\hline
\end{tabular}

both groups have experienced an increase in collaboration, and that men are now more likely to collaborate, it is unlikely that gender can account for the increased collaboration.

Another explanation for the growth relates to the profes-

two authors have ranged from 23 to 34 percent. The greatest growth, however, has been for papers with three to seven authors. Twenty-one percent of the papers given at the last three conferences had that many authors compared to only seven percent of the papers at the first three conferences.

Previous authorship studies have identified two possible explanations. The first attributes the growth in collaboration to the increase in female authors. ${ }^{25}$ Alice Harrison Bahr and Mickey Zemon (2000) suggested that "women are more likely to collaborate than men." ${ }^{26}$ As the number of women presenters increased, one would expect an increase in the overall collaboration rate-as has happened. However, when the collaboration rate for men and women are compared the differences are small. The overall rate for men was 56 percent and that of women 63 percent. (See table 11.)

More important, both groups have been increasing their coauthorship rates over the history of the conference. The rate for women increased from 59 to 72 percent and that for men from 39 to 81 percent. In the last six conferences, men were as likely, or more likely, to coauthor a paper than were women. Given that sion. James Moody, a sociologist, found that "coauthorship is more likely in specialties that admit to an easier division of labor." ${ }^{27}$ Other studies have also identified specialized work expertise as a reason for collaboration..$^{28}$ In examining only coauthors, this study found that there was an increase in the diversity of job titles over time. Seventy-one percent of the coauthors for the first three conferences had different job titles (e.g., one author was a reference librarian and another was a public services librarian). However, for the last three conferences, only 14 percent had similar titles. (See table 11.) Increasingly, one sees authors with different job titles coauthoring a paper. As the profession specializes, the need to collaborate at work and in research has increased.

\section{Comparison with $C \& R L$ authors}

In summary, this study found that authors of contributed papers given at the ACRL conferences tend to be female academic librarians (administrators, reference librar-

\begin{tabular}{|l|c|c|c|c|}
\hline \multicolumn{5}{|c|}{$\begin{array}{c}\text { TABLE 11 } \\
\text { Coauthorship Rates by Gender and Job Heterogeneity } \\
\text { among Coauthors }\end{array}$} \\
\hline \hline Conferences & Years & $\begin{array}{c}\text { Female } \\
\text { Coauthor Rate }\end{array}$ & $\begin{array}{c}\text { Male } \\
\text { Coauthor Rate }\end{array}$ & $\begin{array}{c}\text { Different } \\
\text { Job Titles }\end{array}$ \\
\hline I-III & $1978-84$ & $59 \%$ & $39 \%$ & $71 \%$ \\
\hline IV-VI & $1986-92$ & $57 \%$ & $53 \%$ & $81 \%$ \\
\hline VII-IX & $1995-99$ & $63 \%$ & $65 \%$ & $80 \%$ \\
\hline X-XII & $2001-05$ & $72 \%$ & $81 \%$ & $86 \%$ \\
\hline I-XII & $1978-2005$ & $63 \%$ & $56 \%$ & $81 \%$ \\
\hline
\end{tabular}


ians, or subject specialists) from Doctoral Research institutions in the Midwest. It also identified several trends. During its 27-year history, there have been noticeable increases in the percentage of authors who are women, who are members of the library school faculty, and who represent master's and baccalaureate institutions. There has also been a significant increase in coauthorship of papers. How does this profile, and related trends, compare with the results of $C \mathcal{E} R L$ authorship studies? As "the premier journal of scholarly communication in the field of academic librarianship," ${ }^{29} C \mathcal{E} R L$ is a suitable publication for comparison.

The profile of the authors of the CERL articles is similar in many ways to that of conference presenters. Like the conference profile, $C \mathcal{E} R L$ authors tend to be academic librarians, ${ }^{30}$ with administrators and reference librarians leading in the number of publications. ${ }^{31}$ Likewise, authors tend to represent Doctoral Research institutions. ${ }^{32}$ Many of the same institutions that appeared frequently among conference presenters are also listed in the authorship studies. ${ }^{33}$ Although certain institutions appear frequently, most authors, like presenters, contribute only once. ${ }^{34}$ In addition, most authors, like conference presenters, tend to represent Midwest institutions. ${ }^{35}$ Thus, like the conference, $C E R L$ authors tend to be academic librarians (administrators and reference librarians) from Doctoral Research institutions in the Midwest.

There were also several similar trends. Although Doctoral Research institutions dominate both, there has been an increase in representation from master's and baccalaureate institutions. ${ }^{36}$ Like the conference, the journal has seen an increase in the percentage of female authors ${ }^{37}$ as well as authors who serve as faculty at library schools. ${ }^{38}$ Finally, both means of scholarly communication have seen a notable rise in collaboration. ${ }^{39}$ Although this has been attributed to the increase in female authors, increasing specialization among librarians may be the important factor.
The most noticeable difference between the authors of the ACRL conference papers and $C \mathcal{E} R L$ articles was gender. Although there has been an increase in female presenters and authors, women were more likely to be presenters than authors. Overall, 64 percent of the conference presenters were women compared to only 47 percent of CERL authors. ${ }^{40}$ What would explain this difference? One explanation is the time period studied. There has not been a $C \mathcal{E} R L$ authorship study in the past ten years. It is possible that one will see an increase in female authors as conference presentations lead into later publication. (Theories of scholarly communication suggest that a presentation typically precedes its publication.) However, one doubts if female publication rates have increased to match the high proportion (71\%) of female presenters seen at the last three ACRL conferences. Another explanation is the difference between giving a paper and authoring an article. Several studies have identified how these activities differ. ${ }^{41}$ One of the major differences is that conference papers should "lend themselves to oral presentation." ${ }^{42}$ Is it possible that the oral presentation and direct communication with an audience are preferred by women? Or, is it possible that journal editors and referees prefer papers from occupational subfields in which men are more fully represented (e.g., administrators)? Regardless of the reason for lower publication rates among women, presentation rates among women at ACRL conferences better reflect the profession.

\section{Conclusion}

Amajor function of a conference is to inform and educate. Attending conferences, along with reading the professional literature, are important means of professional development. ${ }^{43}$ Using a competitive process that is similar to that of refereed journal submission, authors of contributed papers at the ACRL conferences are selected to present current research and case studies on best practices. This study provides a profile of 
these authors, specifically their geographic distribution, institutional affiliation, occupation, and gender. It also explores trends in these author characteristics over the history of the conference. A summary of its findings showed the following:

- $38 \%$ of all authors are consistently affiliated with institutions in the Midwest. Conference location has had a minimal impact on the geographic distribution of its presenters.

- 73\% represent Doctoral Research institutions. However, the conference has seen an increase in authors from master's and baccalaureate institutions.

- Although six institutions are frequently represented, $80 \%$ of all authors have given only one paper at the ACRL conferences.

- $89 \%$ of all authors were academic librarians. Among librarians, administrators, reference librarians, and subject specialists were the dominant occupational subcategories represented. The percentage of faculties from library schools, as well as other disciplines, is growing.
- $64 \%$ of all authors are women. Women appear more frequently as presenters at the ACRL conference than as authors of articles in CERL. The proportion of female academic librarians presenting papers appears to be similar to their representation in the profession.

- There has been a $23 \%$ increase in coauthored papers. Gender was not a factor in the increase. Throughout its history, men were as likely to collaborate as women. Rather, it is suggested that as the profession has become more specialized, the need to collaborate increased.

With the exception of gender, the profile and trends were similar to what has been reported in CERL authorship studies. Future studies should explore the role of gender in research and its subsequent presentation or publication.

As the association launches its first totally virtual conference in 2006, one wonders if the authors of its papers will differ greatly from its previous 27 years. This study has provided the groundwork to make these comparisons.

\section{Notes}

1. Association of College \& Research Libraries, "Past National Conferences." Available online at www.ala.org/ala/acrl/acrlevents/nationalconference/pastconferences.htm. [Accessed 25 October 2005].

2. Caroline Coughlin and Pamela Snelson, "Searching for Research in ACRL Conference Papers," Journal of Academic Librarianship 9, no. 1 (Mar. 1983): 24-25; Pamela Snelson and S. Anita Talar, "Content Analysis of ACRL Conference Papers," College E Research Libraries 52, no. 5 (Sept. 1991): 469-71. These studies found that approximately one-third of the papers met selected research criteria and suggest that most papers reflect best practices. Harold B. Shill, review of Continuity and Transformation: The Promise of Confluence: Proceedings of the Seventh National Conference of the Association of College and Research Libraries, ed. Richard AmRhein, Journal of Academic Librarianship 22, no. 6 (Nov. 1996): 470. Shill comments that the papers "included a large number of case studies."

3. C. M. Boissonnas, "Katina's Baby: The Charleston Acquisitions Conference at 15," Library Acquisitions: Practice and Theory 20, no. 3 (1996): 284.

4. Coughlin and Snelson, "Searching," 21-26; Snelson and Talar, "Content Analysis," $466-72$

5. Joseph Fennewald, "Perished or Published: The Fate of Presentations from the Ninth ACRL Conference," College \& Research Libraries (Nov. 2005).

6. Anne L. Buchanan, Edward A. Goedeken, and Jean-Pierre V. M. Hérubel, "Scholarly Communication Among Academic Librarians: An Analysis of Six ACRL Proceedings," Behavioral E Social Sciences Librarian 14, no. 2 (1996): 1-15.

7. Thomas E. Nisonger, "Authorship in Library Acquisitions: Practice \& Theory," Library Acquisitions: Practice \& Theory 20, no. 4 (1996): 395-419.

8. Gloria S. Cline, “College \& Research Libraries: Its First Forty Years," College E Research Libraries 43, no. 3 (May 1982): 208-32; Paul Metz, "A Statistical Profile of College \& Research Libraries," College E Research Libraries 50, no. 1 (Jan. 1989): 42-47; James L. Terry, “Authorship in 
College \& Research Libraries Revisited: Gender, Institutional Affiliation, Collaboration," College $\mathcal{E}$ Research Libraries 57, no. 4 (Jul. 1996): 377-83; Peter Hernon, Allen Smith, and Mary Bailey Croxen, "Publication in College \& Research Libraries: Accepted, Rejected, and Published Papers, 1990-1991," College \& Research Libraries 54, no. 4 (Jul. 1993): 303-21.

9. John N. Olsgaard and Jane Kinch Olsgaard, "Authorship in Five Library Periodicals," College E Research Libraries 41, no. 1 (Jan. 1980): 49-53; Paula D. Watson, "Production of Scholarly Articles by Academic Librarians and Library School Faculty," College E Research Libraries 46, no. 4 (Jul. 1985): 334-42; John M. Budd and Charles A. Seavey, "Characteristics of Journal Authorship by Academic Librarians," College E Research Libraries 51, no. 9 (Sept. 1990): 463-70; Lois Buttlar, "Analyzing the Library Periodical Literature: Content and Authorship," College E Research Libraries 52, no. 1 (Jan. 1991): 38-53; Mickey Zemon and Alice Harrison Bahr, "An Analysis of Articles by College Librarians," College E Research Libraries 59, no. 9 (Sept. 1998): 422-32; William Fisher, "When Write Is Wrong: Is All Our Professional Literature on the Same Page?" Library Collections, Acquisitions, \& Technical Services 23, no. 1 (1999): 61-72.

10. Olsgaard and Olsgaard, "Authorship," 50.

11. National Center for Education Statistics, "Library Statistics Program: Academic Libraries." Available online at http://nces.ed.gov/surveys/libraries/academic.asp. [Accessed July 2004].

12. Association of College \& Research Libraries, "What Is the Association of College \& Research Libraries? Web Survey Results." Available to ACRL members online at www.ala.org/ala/acrl/ aboutacrl/ whatisacrl/whatacrl.htm. [Accessed 25 October 2005].

13. Terry, "Authorship," 379.

14. Janice C. Fennell, ed., Building on the First Century: Proceedings of the Fifth National Conference of the Association of College and Research Libraries (Chicago: American Library Association, 1989), xvii.

15. There have been more authors than papers because so many have been coauthored.

16. Association of College \& Research Libraries, "What Is the Association of College \& Research Libraries? 2003-2004 Annual Report." Available online at www.ala.org/ala/acrl/aboutacrl/ whatisacrl/0304annualreport.htm. [Accessed 25 October 2005].

17. ACRL, "Past National Conferences," online.

18. Of the 700 academic librarians, there were, amazingly, 468 unique occupational titles. With such variation, it was possible that there were errors in placing people in the correct subcategory.

19. Administrators include: Directors, Deans, Assistant or Associate Directors. It also includes Head of Technical Services, as the position oversees several library departments.

20. Subject specialists include a wide variety of subject areas, such as Arts \& Humanities Librarians, Biology Librarian, Education Librarian, and Music Librarian.

21. Circulation librarians include: Public Services, Access Services, and User Services.

22. Mary Jo Lynch, ALA Office for Research and Statistics, "Library Directors: Gender and Salary (1999)." Available online at www.ala.org/ala/hrdr/libraryempresources/librarydirectors. htm. [Accessed 25 October 2005]. This survey identified that $57 \%$ of the academic library directors are women.

23. It was found that $67 \%$ of academic librarians, $59 \%$ of faculty in library schools, and $45 \%$ of faculty in other disciplines who presented papers were women.

24. Mary Jo Lynch, "Library Directors," online.

25. Terry, "Authorship," 381.

26. Alice Harrison Bahr and Mickey Zemon, "Collaborative Authorship in the Journal Literature: Perspectives for Academic Librarians Who Wish to Publish," College E Research Libraries 61, no. 5 (Sept. 2000): 415.

27. James Moody, "The Structure of a Social Science Collaboration Network: Disciplinary Cohesion from 1963 to 1999," American Sociological Review 69 (Apr. 2004): 213-38.

28. Noriko Hara, Paul Solomon, Seung-Lye Kim, and Diane H. Sonnenwald, "An Emerging View of Scientific Collaboration: Scientists' Perspectives on Collaboration and Factors That Impact Collaboration," Journal of the American Society for Information Science and Technology 54, no. 10 (2003): 952-65; Richard L. Hart, "Collaborative Publication by University Librarians: An Exploratory Study," Journal of Academic Librarianship 26, no. 2 (Mar. 2000): 94-99; Richard L. Hart, "Co-authorship in the Academic Library Literature: A Survey of Attitudes and Behaviors," Journal of Academic Librarianship 26, no. 5 (Sept. 2000): 339-45.

29. ACRL, "2003-2004 Annual Report," online.

30. Hernon, Smith, and Croxen, "Publication," 311; Fisher, "When Write," 66; Metz, "Statistical Profile," 44; Olsgaard and Olsgaard, "Authorship," table 4; Watson, "Production," 337.

31. Buttlar, "Analyzing," 42-43; Hernon, Smith, and Croxen, "Publication," 311.

32. Hernon, Smith, and Croxen, "Publication," 311.

33. Hernon, Smith, and Croxen, "Publication," 308; Cline, "College," 214; Budd and Seavey, 
"Characteristics," 468; Watson, "Production," 338.

34. Cline, "College," 213.

35. Buttlar, "Analyzing," 44; Olsgaard and Olsgaard, "Authorship," table 5; using census regions Hernon, Smith, and Croxen found that 35\% of the CERL authors from 1980-91 were from the Midwest (Hernon, Smith, and Croxen, "Publication," 311).

36. Zemon and Bahr's study combined authors of the CERL and JAL and found that there was a 5\% increase in college librarians publishing between 1986-91 and 1992-96. (Zemon and Bahr, "Analysis," 425-26).

37. Metz, "Statistical Profile," 44; Terry, "Authorship," 380-83.

38. Metz, "Statistical Profile," 44; Terry, "Authorship," 380-81.

39. Cline, "College," 215; Metz, "Statistical Profile," 44; Terry, "Authorship," 381.

40. Hernon, Smith, and Croxen, "Publication," 311.

41. See: Coughlin \& Snelson, "Searching," 25; M. Carl Drott, "Reexamining the Role of Conference Papers in Scholarly Communication," Journal of the American Society for Information Science 46, no. 4 (May 1995): 301; William Miller, review of Energies for Transition: Proceedings of the Fourth National Conference of the Association of College and Research Libraries, ed. Danuta A. Nitecki, Journal of Academic Librarianship 12, no. 4 (Sept. 1986): 235; J. C. Rowley, "The Conference Literature: Savory or Acrid?" in Conference Literature: Its Role in the Distribution of Information, ed. Gloria J. Zamora and Martha C. Adamson (Marlton, N. J.: Learned Information, 1981), 11-21.

42. Larry Hardesty, review of Academic Libraries: Myths and Realities: Proceedings of the Third National Conference of the Association of College and Research Libraries, ed. Suzanne C. Dodson and Gary L. Menges, College E Research Libraries 46, no. 5 (Sept. 1985): 442.

43. Ethel Auster and Donna C. Chan, "Reference Librarians and Keeping Up-to-Date," Reference \& User Services Quarterly 44, no. 1 (fall 2004): 59.

\section{We take your order, you take control. -} TRACK YOUR ORDER, EVERY STEP OF THE WAY.

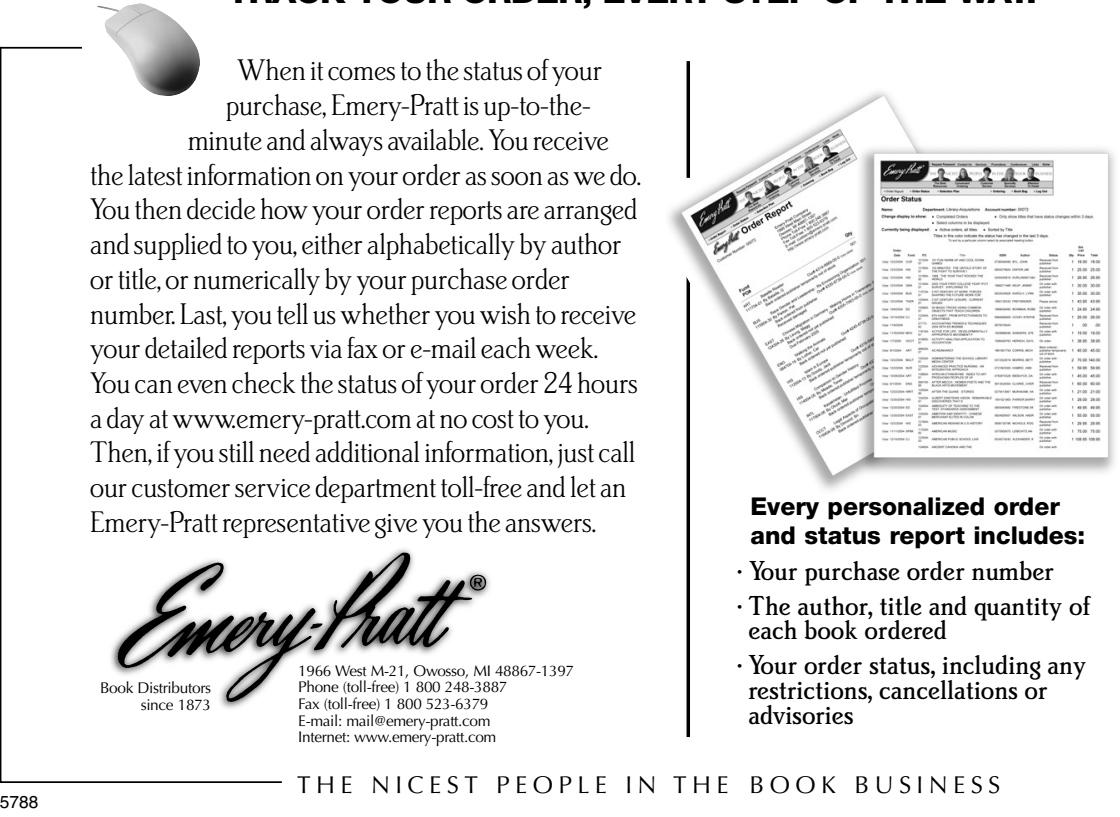

